
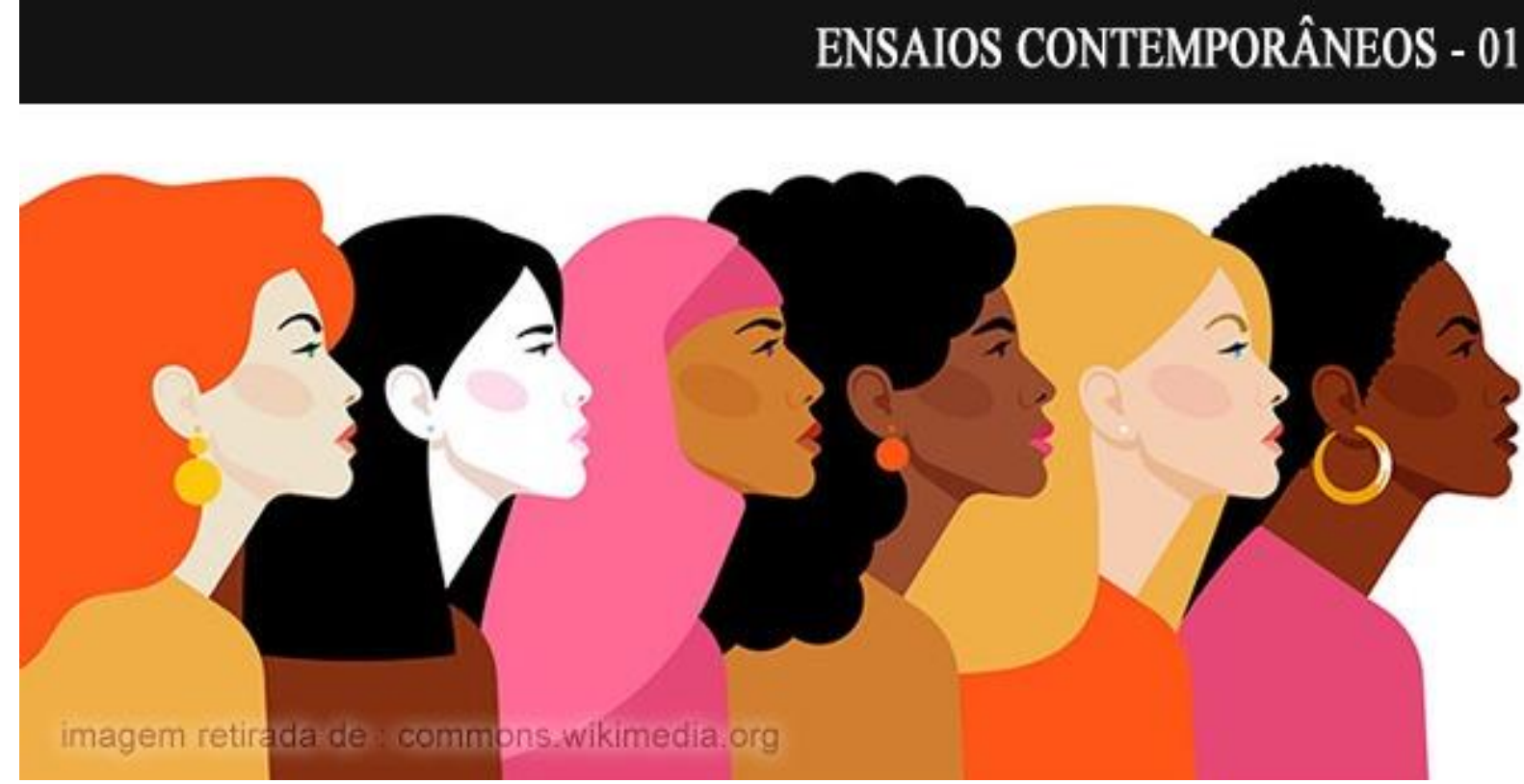

\title{
TRANSGRESSÃO E FEMINILIDADE EM CELEIDA TOSTES: UM FLERTE COM O CAOS
}

\author{
Nicole Soares Resende \\ ORCID: https://orcid.org/0000-0002-3098-5993. \\ E-mail: nicole_resende12@hotmail.com.
}

Resumo: O presente artigo propõe examinar a produção artística de Celeida Tostes, a partir de sua biografia, construída por Marcus de Lontra Costa e Raquel Silva, no livro Celeida Tostes. Busca-se, portanto, analisar os deslocamentos da artista, entre interdito e transgressão, diante da revolução iconográfica proposta em seu trabalho e verificar em que medidas tais transgressões possibilitaram-lhe um encontro com a feminilidade. Para tal, efetivou-se uma pesquisa bibliográfica ancorada no referencial teórico psicanalítico de Freud e Lacan, no que concerne à temática feminilidade, e exploraram-se os estudos de Bataille relativos aos conceitos de transgressão, interdito e erotismo, com vistas a priorizar as convergências existentes entre tais autores. Além disso, para mediar e enriquecer a discussão, foram priorizados estudiosos dos referidos autores, como Butler, Quinet, Nunes e Safatle. Diante do explorado, pode-se constatar que as transgressões empreendidas por Celeida levaram-na a construir suas próprias regras e normas, de modo que, ao colocar seu ser em questão, opôs-se aos juízos e conceitos vigentes no contexto da ditadura militar e da arte concreta. Vê-se, portanto, que a vida e a obra de Celeida são perpassadas por um desejo que se inseriu no furo do Outro e que, dada a impossibilidade de se desvencilhar totalmente desta instância que também a fez desejar, pôde criar alternativas para se articular entre interdito e transgressão, experimentando, assim, um encontro com a feminilidade.

Palavras-chave: Psicanálise. Feminilidade. Transgressão.

\section{TRANSGRESSION AND FEMININITY IN CELEIDA TOSTES: A FLIRT WITH CHAOS}

Abstract: This article proposes to examine the artistic production of Celeida Tostes from her biography, built by Marcus de Lontra Costa and Raquel Silva in the book Celeida Tostes. The aim is, therefore, to analyze the artist's displacements between interdiction and transgression in face of the iconographic revolution proposed in her work and to verify what extent such transgressions enabled her encounter with femininity. To this end, a bibliographic research was carried out anchored in Freud and Lacan's psychoanalytical theoretical referential that concerns to the femininity and explored Bataille's studies relatives to concepts of the transgression, interdiction and eroticism, with the intention of prioritizing the existence of convergences between such author. Besides this, to mediate and

\section{POLÊM!CA $\mid$ LABORE}

Polêmica - Revista Eletrônica da Uerj - Rua São Francisco Xavier, 524, $1^{\circ}$ andar bloco D, sl.1001 • Tels.: +55 21 2334-4088 / 4087 • http://www.e-publicacoes.uerj.br/index.php/polemica/index http://www.labore.uerj.br • laboreuerj@yahoo.com.br 
enrich the discussion were prioritized scholars of these authors, such as Butler, Quinet, Nunes and Safatle. Given the explored, it can be seen that the transgressions undertaken by Celeida led her to construct her own rules and norms, so that, when questioned her being, she opposed the prevailing judgments and concepts in the context of military dictatorship and concrete art. It is seen, therefore, that Celeida's life and work are permeated by a desire that was inserted in the hole of the Other and that, given the impossibility of completely disentangling herself from this instance that also made her want, she could create alternatives to articulate between interdiction and transgression, thus experiencing an encounter with femininity.

Keywords: Psychoanalysis. Femininity. Transgression.

\section{Introdução}

A teoria psicanalítica, desde seu surgimento com Freud, ancorou-se na arte e seu precursor demonstrou um especial interesse por Shakespeare, Goethe, Leonardo da Vinci, dentre outros expoentes. Rivera (2002/2005) enfatiza que a psicanálise e a arte do século XX nasceram juntas e, a partir de então, infindáveis foram seus encontros e desencontros. Uma das confluências entre ambas deu-se ainda em sua origem: a arte rompendo com a perspectiva irredutível da pintura tradicional renascentista e a psicanálise desestabilizando as noções rígidas, patologizantes e adaptacionistas de sujeito, levando Freud (1900/1996, p. 223) a anunciar que "só podemos descrever as coisas com a ajuda de analogias", as quais, assim como a arte e a psicanálise, estão em constante transformação.

Deste modo, o sujeito que antes era concebido em sua 'relação' com a cultura, passa a ser considerado 'na' cultura e desta não-relação, obtém-se certa dose de conforto, mas leva-se também ao inevitável mal-estar inerente aos seres cindidos pela linguagem, pois ainda que haja a apropriação da cultura - e isso se dá à revelia do sujeito, dado que ninguém está foracluído dela - ela sempre estará no campo do Outro. Logo, “[...] trata-se de alienar-se, já que significa ter sua essência fora de si, ter seu modo de desejar e de pensar moldado por um outro" (SAFATLE, 2017/2018, p. 23), o que implica na internalização de modelos específicos de conduta socialmente legitimados.

A arte opera também como uma satisfação substitutiva diante da impossibilidade da adequação do desejo aos objetos empíricos, o que para Freud (1900/1996) não passa de ilusão, apesar de sua efetividade psíquica no nível da fantasia. Caminhando um pouco além da superficialidade, Rivera (2014) acrescenta que as manifestações artísticas informam sobre o real - instância que mais se aproxima do inconsciente - através de sua inscrição no imaginário, o que faz com que a obra não se esgote na obviedade aparente da imagem. Cumpre ponderar que este fato não implica em um saber teórico do artista, muito pelo contrário, trata-se dos “"[...] modos como o simbólico pode revirar o imaginário para fazer surgir reverberações no real"

\section{POLÊM!CA $\mid$ LABORE}

Polêmica - Revista Eletrônica da Uerj - Rua São Francisco Xavier, 524, $1^{\circ}$ andar bloco D, sl.1001 • Tels.: +55 21 2334-4088 / 4087 • http://www.e-publicacoes.uerj.br/index.php/polemica/index http://www.labore.uerj.br • laboreuerj@yahoo.com.br 
(RIVERA, 2014, p. 246), dados, justamente, a partir dos deslocamentos provocados pela arte e que só podem ser analisados um a um.

Portanto, não se podem tomar psicanálise e arte como campos contínuos, visto que há uma correspondência faltosa entre ambas. É o real, o impossível, o inapreensível que insiste em retornar, contrapondo-se à aparência de ordenação da sublimação, posto que "toda arte se caracteriza por um certo modo de organização em torno do vazio" (LACAN, 1959-1960/2008, p. 162), o que revela a multiplicidade viva do desejo puro, ou seja, daquele que se manifesta como inadequação e estranhamento de si mesmo em relação ao Eu (SAFATLE, 2017/2018).

No afã de encontrar um posicionamento pacificador entre psicanálise e arte, com promessas de felicidade e completude, depara-se com o nada, o qual não deve ser encarado como ausência de direção e sim, como abertura a todo o possível. Rivera (2002/2005, p.67) alerta que esse des-encontro não trata de um lugar, mas, precisamente, de uma "[...] oscilação constante" que caminha sem as promessas do renascimento e das convicções interpretativas absolutas da psicanálise diante das obras de arte. Assim, este fato a convoca, enquanto corpo errante, a desalojar-se do consultório e procurar novas auroras.

Em vista disso, este ensaio envolve a análise documental do livro Celeida Tostes, organizado por Marcus de Lontra Costa e Raquel Silva (2014), diante do qual se propõe examinar a produção artística de Celeida Tostes, a partir de tal biografia. A escolha do objeto se justifica, sobretudo, por colocar a psicanálise diante da arte, de modo que o saber desta possa fazer avançar a própria teoria, na medida em que se distancia da busca reducionista por uma complementaridade e continuidade entre ambas.

Intenta-se, portanto, analisar os deslocamentos da artista entre interdito e transgressão, diante da revolução iconográfica proposta em seu trabalho e verificar em que medida tais transgressões possibilitaram-lhe um encontro com a feminilidade. Para tal, foi efetivada uma pesquisa bibliográfica ancorada no referencial teórico psicanalítico de Freud, pautada nos seguintes textos: A feminilidade (1933/2010); A identificação (1920-1923/2012) e Algumas consequências psíquicas da distinção anatômica entre os sexos (1925/1996). Em conformidade com os estudos de Freud relativos às temáticas feminilidade e identificação, buscou-se também a obra de Lacan, privilegiando os escritos: A identificação (1960-1962/2003); O seminário, livro 7: a ética da psicanálise (1959-1960/2008); Diretrizes para um congresso sobre a sexualidade feminina (1966/1988a); O estádio do espelho como formador da função do eu

\section{POLÊM!CA $\mid$ LABORE}

Polêmica - Revista Eletrônica da Uerj - Rua São Francisco Xavier, 524, $1^{\circ}$ andar bloco D, sl.1001 • Tels.: +55 21 2334-4088 / 4087 • http://www.e-publicacoes.uerj.br/index.php/polemica/index http://www.labore.uerj.br • laboreuerj@yahoo.com.br 
(1966/1988b); O homem e A mulher (1971/2009); O seminário, livro 19: ... ou pior (19711972/2012); e O seminário, livro 20: mais, ainda (1972-1973/2008).

Os estudos de Freud, Lacan e Bataille, relativos aos conceitos de transgressão, interdito e erotismo, foram explorados, no intuito de destacar suas convergências, sendo fundamentados nos textos: A noção de dispêndio (1949/2016); História do olho (1928/2018); A experiência interior (1943/1992); e O erotismo (1957/2017). Ademais, foram convocados para mediar e enriquecer este trabalho, estudiosos dos referidos autores, como Butler, Quinet, Nunes e Safatle. Por fim, partiu-se do pressuposto de que toda arte é nua, pois desvenda e desnuda o imponderável. O que, afinal, a nudez de Celeida Tostes comunica? Será possível encontrar uma resposta? Talvez o leitor se despindo também consiga, na medida em que se vê na obra a cada olhar e a cada comentário. Eis um espelho que não apenas reflete, mas igualmente subverte. Desnude-se, pois!

\section{Revisão de literatura}

$\underline{\text { Eu me vejo em você }}$

Sou como você me vê. Posso ser leve como uma brisa ou forte como uma ventania, depende de quando e como você me vê passar

Clarice Lispector.

Quem é este outro que se parece tanto comigo? Ou ainda, quem sou eu que me pareço tanto com esse outro? Freud (1920-1923/2012) já constatara a dependência do eu, ao notar que a criança se liga à mãe e ao pai, capturando a primeira como objeto de investimento libidinal direto e o último, como modelo, pela via da identificação. É o encontro entre ambas as ligações que culmina no complexo de Édipo, no qual, não raro, há inversões no tocante ao objeto e à identificação. Assim, ora o falo atua como aquilo que a infans gostaria de ter, ora como aquilo que ela gostaria de ser, o que faz com que o eu se esforce para corresponder à imagem e semelhança da pessoa que odeia ou da que ama.

É aí que surge o herdeiro do narcisismo primário, ou mais precisamente, o ideal do eu ${ }^{1}$. É essa instância, que, aos poucos

\footnotetext{
${ }^{1} \mathrm{O}$ ideal do eu consiste em uma instância formada a partir do Complexo de Édipo e influenciada por valores culturais. Nele, há uma substituição simbólica dos pais idealizados por novas figuras, fugindo assim, da imposição

\section{POLÊM!CA $\mid$ LABORE}

Polêmica - Revista Eletrônica da Uerj - Rua São Francisco Xavier, 524, $1^{\circ}$ andar bloco D, sl.1001 • Tels.: +55 21 2334-4088 / 4087 • http://www.e-publicacoes.uerj.br/index.php/polemica/index http://www.labore.uerj.br • laboreuerj@yahoo.com.br
} 
[...] acolhe, das influências do meio, as exigências que este coloca ao Eu, as quais o Eu nem sempre é capaz de cumprir, de modo que o indivíduo, quando não pode estar satisfeito com seu Eu em si, poderia encontrar satisfação no ideal do Eu que se diferenciou do Eu (FREUD, 1920-1923/2012, p. 52).

Suas investigações apontam para a simbiose existente entre o eu e o outro ${ }^{2}$, em um processo de confusão generalizada de intenções, pensamentos e emoções. Esse outro é igual e rival e ocupa, portanto, o lugar de outro-ideal, visto que "constituído pela imagem do outro, o eu está para sempre alienado ao seu outro-ideal" (QUINET, 2012, p. 6).

Conduzindo suas inquirições neste sentido, o que Lacan (1996/1998) descortinou anos mais tarde, ao analisar o estádio do espelho, foi justamente o fato de que, para o homem se considerar um eu, ele precisa da inscrição, no registro do imaginário, da identificação com a imago do semelhante, bem como do ciúme primordial, os quais inauguram, assim, a dialética que aproxima o eu das circunstâncias socialmente produzidas. Logo, o outro ocupa o lugar de eu ideal, na medida em que é constituído pelos significantes vinculados ao desejo do Outro, forjados pelo ideal do eu, ou melhor, ideal do Outro, significantes estes inconscientes e que foram recalcados a partir das imposições sociais e culturais do 'você tem que ser assim'.

Safatle (2017/2018) afirma que se identificar é se alienar, pois implica em ter os desejos e pensamentos forjados pelo outro. Ainda, trata-se de um processo marcado por intensas repressões, visto que está orientado por normas e padrões gerais que limitam as satisfações incondicionais e que, consequentemente, pode desembocar no ódio profundo por tudo aquilo que entendemos como ideal.

Deste modo, segundo Quinet (2012) para sentir-se amado, o sujeito tentará, a todo custo e impulsionado ainda mais por suas exigências narcísicas, se adaptar aos significantes ditados pelo Outro através da identificação simbólica, organizando-se segundo seu eu ideal, por meio da identificação imaginária, que é da ordem do outro. Este fato se dá, pois, ao Outro falta um significante que lhe dê consistência enquanto estrutura fechada e é nesse furo que o sujeito irá se articular.

do eu projetada por sua autoridade fundadora. O eu ideal é sua base e surge como resultado do narcisismo dos pais. Ele é caracterizado por um estado de autossuficiência, ao qual o sujeito renuncia frente às críticas e exigências sociais, inserindo-se no ideal do eu. Portanto, o eu ideal e o ideal do eu constituem a imagem do ser (FREUD, 1914/1987).

2 Em Lacan, os termos "outro" e "Outro" se distinguem ao passo que o primeiro designa o semelhante, frente ao qual o eu pode admirar, odiar, invejar e/ou identificar-se. E o segundo é considerado como um lugar do discurso do inconsciente, ou ainda, é onde o sujeito é pensado, onde se inscrevem as determinações simbólicas que marcaram o sujeito antes mesmo de seu nascimento, como a lei, a história e a cultura (QUINET, 2012).

\section{POLÊM!CA $\mid$ LABORE}

Polêmica - Revista Eletrônica da Uerj - Rua São Francisco Xavier, 524, $1^{\circ}$ andar bloco D, sl.1001 • Tels.: +55 21 2334-4088 / 4087 • http://www.e-publicacoes.uerj.br/index.php/polemica/index http://www.labore.uerj.br • laboreuerj@yahoo.com.br 
É por isso que desvencilhar-se do Outro é uma tarefa impossível, visto que, como pondera Butler (2005/2017) todo eu sofre diretamente as implicações das normas morais e das condições sociais que possibilitaram seu surgimento, de tal forma que o sujeito encontra-se limitado a um sistema que prevê o que é aceitável ou não. Portanto, não existe, no regime discursivo em que todo ser humano está inserido, um significante que seja por fim, puramente pessoal.

Onde nasce esse ser cingido pelo Outro? Qual é, afinal, o lugar do sujeito, dado que ao longo de toda vida há a busca por uma base sólida onde se firmar? Acontece que, por estrutura, o Outro não traz em si a completude, dádiva tão sonhada na neurose. Ele falta. Não obstante, Safatle (2017/2018, p. 37) pondera que é justamente neste "si mesmo estranho ao Eu", herdeiro da castração, que surge o desejo.

E, apesar da busca incessante para tamponar essa ausência, o máximo que se consegue é sua satisfação parcial, pois há uma dissimetria entre o sujeito e o objeto causa de seu desejo. Entretanto, é justamente neste ponto em que o sujeito pode advir, desvencilhando-se, tanto quanto possível, da alienação que o marcara até então, pois “o sujeito é representado, mas não é um elemento do Outro. O lugar do sujeito é o furo do Outro" (QUINET, 2012, p. 15).

É nessa hiância do Outro que pode advir um sujeito desejante, mas que também não pode desejar qualquer coisa. O seu desejo está vinculado ao desejo do Outro e daí surgem, por exemplo, algumas frases estereotipadas relativas ao papel social da mulher e ao amor: "Você nunca vai conseguir um namorado, agindo assim"; "Não precisa ficar triste, você é muito mais linda do que ela"; "Toda mulher só é completa quando se torna mãe"; "Ela é mal-amada, malcomida".

Essas e tantas outras frases demonstram como o desejo, que é sempre desejo de reconhecimento, está mais ou menos alienado ao desejo do Outro e por isso, desvela "“...] a falta constitutiva da estrutura e do Outro" (SAFATLE, 2017/2018, p. 86). Portanto, o desejo está em constante contradição com o campo discursivo habitado pelo ser falante, o qual é construído sociossimbolicamente, o que faz com que, para dizer de fato quem se é, como afirma Clarice Lispector, dependerá de quando e como o Outro nos vê passar, afinal, 'eu' me vejo em 'você'.

\section{POLÊM!CA $\mid$ LABORE}


$\underline{\text { Feminino transbordante }}$

Dos rótulos lancei ao fogo todas as memórias. Agora sou o que tange as tardas horas e em teus anéis arabesco um resplendor de equinócio. Não sou o que advém, nem sou o que adfoi. Eu sou o imprevisto vestido de ternura

Roberto Pontes.

Lançar as memórias dos rótulos ao fogo, tal qual fez Roberto Pontes em sua poesia e construir uma possibilidade infinita de 'ser' é uma tarefa árdua que tem sua gênese no Outro e desemboca no encontro com a feminilidade. Lacan (1971-1972/2012, p. 117), ao posicionar o Outro em um 'entre', assevera que este enunciado se refere à mulher, pois "ela quem nos dá, dessa figura do Outro, a ilustração ao nosso alcance, por estar, como escreveu um poeta, entre o centro e a ausência”.

Eis porque o feminino é transbordante: ainda que perpassado por uma alteridade - o Outro -, não há barreiras que o possa limitar. É preciso, portanto, enfatizar que não se trata, aqui, do gênero feminino, mas, precisamente, do que Freud (1993/2010) há muito descortinara: "o que constitui a masculinidade ou a feminilidade é uma característica desconhecida que a anatomia não pode apreender" (p. 266).

Em Algumas consequências psíquicas da diferença anatômica entre os sexos, Freud (1925/1996) concluiu que tanto as meninas quanto os meninos têm a feminilidade encorajada em detrimento da masculinidade, através da castração, embora esta opere de forma análoga para ambos, visto que para as primeiras constitui uma punição concretizada, enquanto para os outros, uma advertência. Este fato se dá de tal forma, que é o menino e não a menina, quem teme ser castrado. Assim, já que a menina não tem o falo, ela irá investir sua libido no seu desejo de ter um filho - bebê-falo.

Entretanto, a equação pênis-filho demonstra como algo relativo ao desejo da mulher permanece suspenso, visto que ser mãe e ser mulher não são proposições equivalentes. A biologia já atestara e quanto a isto não há dúvida: há uma diferença no que tange aos órgãos sexuais e que Lacan (1971-1972/2012, p. 17) denominou como a "pequena diferença". Diante desta há, portanto, um preço a se pagar, posto que, como um instrumento que atinge o real, ele só pode ser encarado como um significante e como tal, o falo intervém majestosamente.

Logo, a questão não se circunscreve em demarcar os significantes homem e mulher ou mesmo em nomeá-los como y ou x, o que importa é justamente o fato de que são os seres forjados pela linguagem, que se distinguem. Assim, as bases erguidas por Freud (1925/1996),

\section{POLÊM!CA | LABORE}

Polêmica - Revista Eletrônica da Uerj - Rua São Francisco Xavier, 524, $1^{\circ}$ andar bloco D, sl.1001 • Tels.: +55 21 2334-4088 / 4087 • http://www.e-publicacoes.uerj.br/index.php/polemica/index http://www.labore.uerj.br • laboreuerj@yahoo.com.br 
com sua investigação relativa à castração, levam à conclusão de que esta, enquanto operação simbólica, é válida para ambas as anatomias, ao passo que é ela quem torna os seres falantes faltosos.

Encontra-se aí a representação maior do falo, ou seja, servir de mediador para que o desejo do sujeito possa se tornar reconhecível, trazendo em si a marca da inadequação existente entre este e os objetos empíricos. Trata-se, por fim, de "um significante puro, uma diferença pura que organiza posições subjetivas (masculino/feminino)" (SAFATLE, 2017/2018, p. 57), haja vista que, como demonstrado por Freud (1933/2010), a libido não tem gênero e, portanto, deve ser considerada diante das polaridades masculino-feminino.

Assim, é por estar entre o centro e a ausência que a mulher escapa ao significante que diferencia masculino e feminino. O que há, por fim, para cada sujeito, são diferentes formas de gozar com o Outro, essa alteridade essencial. Considerando que a operação simbólica, ou seja, a incidência da linguagem, torna o sujeito inapreensível, fazendo-o um 'ser sem ser', o que lhe resta é a existência. Em outras palavras: já que o sujeito não pode ser, contenta-se em depender do Outro (LACAN, 1971-1971/2012).

É precisamente aqui que Lacan (1972-1973/2008) situa o gozo suplementar, ou ainda, o gozo dA mulher, desta que, por ser não-toda, só pode ser escrita barrando-se o A, já que A mulher não existe e, portanto, não pode ser universalizada. Deste modo:

O ser sexuado dessas mulheres não-todas não passa pelo corpo, mas pelo que resulta de uma exigência lógica na fala. Com efeito, a lógica, a coerência inscrita no fato de existir a linguagem e de que ela está fora dos corpos que por ela são agitados, em suma, o Outro que se encarna, se assim se pode dizer, como ser sexuado, exige esse uma a uma (LACAN, 1972-1973/2008, p. 17).

Em suma, é próprio desse significante 'a' não significar nada e por isso, ser da ordem do infinito. Mas, o que se produz do gozo feminino ao se deparar com sua própria ausência, dada a impossibilidade de se escrever a relação sexual já anunciada por Lacan (19711972/2012)? É em razão de tal impossibilidade, marcada pelo fato de que o homem goza com o órgão, sustentado pelo imaginário e a mulher, com o corpo, regido pelo simbólico que ela usufrui de uma “enorme liberdade com o semblante" (LACAN, 1971/2009, p. 34) e pode assim, criar-se e recriar-se.

Neste âmbito, Butler (2005/2017) destaca que “[...] só podemos reconhecer e ser reconhecidos sob a condição de sermos desorientados por algo que não somos, sob a condição

\section{POLÊM!CA $\mid$ LABORE}

Polêmica - Revista Eletrônica da Uerj - Rua São Francisco Xavier, 524, $1^{\circ}$ andar bloco D, sl.1001 • Tels.: +55 21 2334-4088 / 4087 • http://www.e-publicacoes.uerj.br/index.php/polemica/index http://www.labore.uerj.br • laboreuerj@yahoo.com.br 
de experimentarmos uma descentralização e 'fracassar' na tentativa de alcançar nossa identidade pessoal" (p. 60). Sua afirmação demonstra como o encontro fracassado com o Outro, ou ainda, a descoberta real da impossibilidade de ser A mulher diante das exigências do Ideal de eu, leva o sujeito ao questionamento de si e à abertura para o imponderável, para o nada.

Vê-se o dilaceramento do encontro com a feminilidade: será que assim ainda serei reconhecida pelo outro? Quem serei eu, sem reconhecimento? Lacan (1966/1998), em Diretrizes para um congresso sobre a feminilidade, destaca que "o homem serve aqui de conector para que a mulher se torne esse Outro para ela mesma, como o é para ele" (p. 741), ou seja, é através da inexistência da relação sexual, a qual prescinde de reciprocidade, que a feminilidade advém, nesta alteridade assimétrica que coloca o feminino diante do a-sexuado da existência e que é irrepresentável. É justamente por ser assim que ela pode se questionar do seu 'eu, mulher' e finalmente, lançar ao fogo as memórias dos rótulos que lhe subjugam e ser como o poeta Roberto Pontes: "nem o que advém, nem o que adfoi, mas o imprevisto, vestido de ternura" - ou do que ela quiser.

\section{Um salto no impossível}

Mas o que eu não gosto é do bom gosto, eu não gosto do bom senso, eu não gosto dos modos, não gosto. Eu gosto dos que têm fome, dos que morrem de vontade, dos que secam de desejo, dos que ardem.

Adriana Calcanhotto.

Este ensaio tem conduzido a uma constatação arrebatadora: o sujeito não pode prescindir do Outro, mas ao mesmo tempo é impossível que seja uma unidade, idêntica e indissociável. Por onde se deve, portanto, caminhar, se quando se diz "deve”, essa palavra já soa como um imperativo que interdita? Seria admissível dar um salto no impossível? E ainda, seria possível com esse salto, encontrar a famigerada feminilidade?!

Neste sentido, Lacan (1972-1973/2008, p. 155) indaga: “será que a palavra interdição quer dizer mais, será mais permitido ainda?", questionamento este que leva de encontro a Bataille, o poeta do indizível. Em seu livro O erotismo, Bataille (1957/2017) postula que a vida social é definida pela articulação entre interdito e transgressão, visto que ela está tão sujeita a regras quanto o primeiro. Assim, a transgressão não pressupõe a retirada dos limites, mas a sua superação, através de uma atividade organizada que tem na lei seu ponto de partida e de chegada.

\section{POLÊM!CA $\mid$ LABORE}

Polêmica - Revista Eletrônica da Uerj - Rua São Francisco Xavier, 524, $1^{\circ}$ andar bloco D, sl.1001 • Tels.: +55 21 2334-4088 / 4087 • http://www.e-publicacoes.uerj.br/index.php/polemica/index http://www.labore.uerj.br • laboreuerj@yahoo.com.br 
Vemos porque o poeta confirma a premissa lacaniana, já que com a transgressão, o homem se abre para o erotismo, o qual, “[...] em seu conjunto é infração à regra dos interditos: é uma atividade humana" (BATAILLE, 1957/2017, p. 118). Não obstante, o encontro com o desejo erótico se dá apenas através do rompimento da continuidade na ordem descontínua, ou seja, quando o erotismo, enquanto experiência interior dispensa a utilidade tão disseminada na continuidade, que carece da duração como uma fantasia de religar-se ao ser, em sua essência primeira. Eis a angústia humana: deparar-se com o descontínuo, com a constatação de que o homem é uma individualidade perecível.

Apesar desta dura descoberta, é com o erotismo que o desejo pode advir, "é do lado de lá da fronteira ultrapassada que o desejo começa” (LACAN, 1960-1962/2003, p. 289), é quando o sujeito abandona a ilusão da continuidade e assume seu próprio desejo ${ }^{3}$. Portanto, “[...] uma transgressão é necessária para aceder a esse gozo [...]" (LACAN, 1959-1960/2008, p. 212) e ir contra condições de vida mortificantes que o sujeito não pode escolher. Butler (2005/2017) adverte que, se essa relativa liberdade funciona de algum modo, é justamente por ser motivada por um campo restritivo e limitador e para isso, é preciso um mais além, uma passagem violenta que rompa com as formas sociais constituídas, como o fazem o narrador e Simone em a História do olho:

\footnotetext{
Chupava o seio de Simone enquanto esperava os ovos quentes. Ela acariciava a minha cabeça. Sua mãe nos trouxe os ovos. Não virei a cabeça. Tomando-a por uma criada, continuei. Quando reconheci sua voz, continuei imóvel, sem renunciar ao seio nem por um instante; baixei as calças, como quem tivesse que satisfazer uma necessidade, sem ostentação, mas como o desejo de que ela fosse embora e como o prazer de ultrapassar os limites. (BATAILLE, 1928/2018, p. 40).
}

Assim, as transgressões dos personagens atestam que, ainda que a cultura subjugue o desejo do sujeito às suas leis, é na medida em que ela interdita que possibilita a mínima abertura da experiência para o excesso, para o gozo que transborda a busca por uma duração indefinida. Diante de um mundo simbólico ordenado por restrições da moral sexual civilizatória, "a linguagem é uma casa de tortura na qual o sujeito se instala e na qual ele é convocado a inventar para si um lugar" (NUNES, 2012, p. 88).

\footnotetext{
${ }^{3}$ Lacan (1959-1960/2008) é assertivo ao afirmar a ética da pluralidade do desejo, de tal modo que este não se trata, aqui, de uma exigência desmedida e irrenunciável. Distintamente, é quando não se cede a um desejo que se descobre um desejo qualquer, que é pura negatividade, justamente por romper com a normalidade da busca por suas correspondências com os objetos disponíveis no registro sociossimbólico.
}

\section{POLÊM!CA $\mid$ LABORE}

Polêmica - Revista Eletrônica da Uerj - Rua São Francisco Xavier, 524, $1^{\circ}$ andar bloco D, sl.1001 • Tels.: +55 21 2334-4088 / 4087 • http://www.e-publicacoes.uerj.br/index.php/polemica/index http://www.labore.uerj.br • laboreuerj@yahoo.com.br 
Aqui há um impasse. Inventar para si um lugar exige assumir o próprio desejo, o que inevitavelmente, remete ao conforto de permanecer no desejo sem o exceder. A um passo do paraíso. Busca-se a duração, mas duração do quê? Se nessa busca incessante por um gasto produtivo, de fato não se alcança a vida?! Se "sabemos que a posse desse objeto que nos queima é impossível” (BATAILLE, 1957/2017, p. 166), ou ainda, se ele está na ordem do real?! Afinal, para onde vai o sujeito aspirante ao desejo?

Lacan (1971-1972/2012) destaca que o real comanda a função da significância, a qual o sujeito não consegue segurar, ao menos, não a todos os significantes ao mesmo tempo. Assim, pela operação do recalque, só podemos dar notícia de alguns, mas isso não nos impede de dizêlos censuradamente “ainda assim” (p. 29). A recomendação de Lacan leva-nos à constatação de que o erotismo, marcado pela clivagem dos códigos comuns, não consiste no retorno à animalidade. Distintamente, a experiência interior impulsiona o questionamento da linguagem, agora, não mais como referência absoluta, mas como um artifício que permite ao sujeito não apenas aspirar pelo desejo, mas ascender como sujeito desejante (NUNES, 2012).

O impossível da experiência interior se dá, porque o desejo está tanto do lado da transgressão quanto da lei do Outro. Isso significa, como já constatamos, que o eu não se separa das normas éticas e morais que constituem sua matriz sociossimbólica, visto que essa é também a condição para seu surgimento. É por isso que é inadmissível pensar corpo, gênero e sexualidade, por exemplo, desvencilhando-os das relações de poder, ou ainda, da lei heteronormativa que regula a sexualidade humana, visto que

\footnotetext{
O corpo feminino liberto dos grilhões da lei paterna pode se mostrar apenas uma outra encarnação dessa lei, que posa de subversiva, mas opera a serviço da autoampliação e proliferação da lei. Para evitar a emancipação do opressor em nome do oprimido, temos de levar em conta toda a complexidade e sutileza da lei, e nos curarmos da ilusão de um corpo verdadeiro além da lei. Se a subversão for possível, será uma subversão a partir de dentro dos termos da lei, por meio das possibilidades que surgem quando ela se vira contra si mesma e gera metamorfoses inesperadas. O corpo culturalmente construído será então libertado, não para seu passado 'natural', nem para seus prazeres originais, mas para um futuro aberto de possibilidades culturais. (BUTLER, 1990/2018, p. 164).
}

Vê-se, portanto, que um futuro aberto de possibilidades se dá na medida em que o sujeito consegue dar um salto no impossível, se articulando entre interdito e transgressão em um

\section{POLÊM!CA $\mid$ LABORE}

Polêmica - Revista Eletrônica da Uerj - Rua São Francisco Xavier, 524, $1^{\circ}$ andar bloco D, sl.1001 • Tels.: +55 21 2334-4088 / 4087 • http://www.e-publicacoes.uerj.br/index.php/polemica/index http://www.labore.uerj.br • laboreuerj@yahoo.com.br 
movimento contínuo, para assim, gozar ${ }^{4}$. E para gozar, é necessário admitir a castração e o encontro com a alteridade de um corpo que, por ser marcado pela linguagem, nunca encontrará uma satisfação total. Dar um salto no impossível implica secar e arder em desejo, recusar e aceitar esse Outro que sufoca e liberta. Que é o encontro com a feminilidade se não a abertura a todo possível, a escolha de seu destino, mesmo diante de tantos imperativos culturais e sociais?! Em uma civilização perpassada pelo consumo e pelas exigências de produtividade, a feminilidade é uma saída para quem, como Adriana Calcanhotto, tem coragem de abdicar-se dos bons modos, do bom senso e entregar-se ao desejo, ao nada, à inutilidade, enfim, à vida.

\section{Desenvolvimento}

\section{Celeida Tostes e seus 66 anos de criação}

Celeida Tostes nasceu no Rio de Janeiro, em 1929, onde viveu até sua morte, aos 66 anos, em 1995. A artista cresceu no interior fluminense, na Fazenda de Campo Alegre, em Macuco, sob os cuidados de tias e avós maternos, em decorrência da morte de sua mãe, quando tinha apenas um ano de vida. Sua infância foi marcada por brincadeiras no rio e no barro molhado, até que aos 17 anos começou a trabalhar como datilógrafa na loja de ferragens Cofermat, ainda no Rio de Janeiro. Foi neste contexto que descobriu sua identificação com o desenho, pois a ausência de alguém que desenhasse as ferramentas que seriam reconhecidas no balanço anual da loja, fez com que ela desempenhasse tal função (COSTA; SILVA, 2014).

Ferreira e Silva (2014) destacam que a artista trabalhou também como auxiliar de administração e desenhista no Instituto de Aposentadoria e Pensões dos Comerciários (IAPC), entre 1946 e 1961, e posteriormente, foi recreadora hospitalar na Casa de Saúde Doutor Eiras e no Hospital dos Comerciários, atuando respectivamente no setor de doenças mentais e ortopedia. Aos 21 anos, em 1950, Celeida passou em primeiro lugar, no curso de gravura do vestibular da Escola Nacional de Belas Artes (ENBA), da Universidade do Brasil, onde se graduou em 1955.

Em 1956, fez o curso de Educação Artística para Professores, na Escolinha de Arte do Brasil, e se tornou licenciada em desenho, em 1957. Um ano depois, especializou-se em

\footnotetext{
${ }^{4} \mathrm{O}$ termo ao qual no referimos não se trata de orgasmo. Fazemos aqui uma retomada ao conceito lacaniano de gozo, derivado do francês "lajouissance", enquanto escrita interditada àquele que fala, tanto do lado do gozo fálico, quanto do gozo outro e que não se restringe ao prazer-desprazer.
}

\section{POLÊM!CA | LABORÊ}

Polêmica - Revista Eletrônica da Uerj - Rua São Francisco Xavier, 524, $1^{\circ}$ andar bloco D, sl.1001 • Tels.: +55 21 2334-4088 / 4087 • http://www.e-publicacoes.uerj.br/index.php/polemica/index http://www.labore.uerj.br • laboreuerj@yahoo.com.br 
Educação Secundária, como aluna bolsista, na Universidade Southern, na Califórnia e na Universidade New Mexico Highlands, onde teve a oportunidade de ser estagiária da índia navajo Maria Martinez, a qual lhe ensinou técnicas de manipulação do barro. Ferreira e Silva (2014) destacam que tal experiência foi fundamental para a escolha do barro enquanto matériaprima de seu trabalho. Em retorno ao Brasil, Celeida pode aplicar os conhecimentos acumulados nos anos anteriores no Parque Lage, o qual permitiu o encontro de sua atuação enquanto artista plástica e educadora.

Neste ínterim, seu trabalho se desenvolveu em um contexto muito específico. O universo artístico da década de 50, no Brasil, vivenciava a ascensão dos movimentos concretistas e neoconcretistas, sendo que o primeiro surgiu precisamente, em 1952, na cidade de São Paulo, com a exposição do Grupo Ruptura. Seus principais expoentes foram AnatolWladyslaw, Lothar Charoux, Féjer, Geraldo de Barros, Leopold Haar, Luiz Sacilotto e Waldemar Cordeiro, os quais buscavam uma arte geometrizada que se aproximasse da produção industrial e rompesse com o abstracionismo existente até então (SANTOS; NEVES, 2010).

Em resposta ao concretismo, como destacado por Santos e Neves (2010), eclodiu em 1959, no Rio de Janeiro, o neoconcretismo, a partir da publicação de um manifesto no Suplemento Dominical do Jornal do Brasil. Artistas como Amilcar de Castro, Ferreira Gullar, Franz Weissmann, Lygia Clark, Lygia Pape, Reynaldo Jardim e Theon Spanudis denunciaram a padronização da experiência artística presente no concretismo, defendendo a liberdade de expressão, experimentação e criação. Outrossim, repudiaram a rigidez geométrica, o mecanicismo e o cientificismo concreto em nome da concepção do observador como partícipe da obra (SANTOS; NEVES, 2010). Com tudo isso, o movimento neoconcreto é de extrema relevância para a contextualização da produção de Celeida, pois além de morar no Rio de Janeiro durante sua eclosão, podemos notar em seu trabalho, uma preocupação formal com as mesmas questões propostas pela ideologia neoconcretista, como será demonstrado a diante.

Entre a matéria-prima e a arte: uma poética da transgressão e da feminilidade

A pintura e a escultura eram, até o início da década de 60, duas categorias dominantes no cenário da arte. Sielski (2009) afirma que foram os artistas neoconcretos quem operaram as

\section{POLÊM!CA $\mid$ LABORE}

Polêmica - Revista Eletrônica da Uerj - Rua São Francisco Xavier, 524, $1^{\circ}$ andar bloco D, sl.1001 • Tels.: +55 21 2334-4088 / 4087 • http://www.e-publicacoes.uerj.br/index.php/polemica/index http://www.labore.uerj.br • laboreuerj@yahoo.com.br 
maiores transformações na arte, entre a década de 60 e 70, em resposta à racionalidade ${ }^{5}$ da arte do Modernismo, ou seja, à clareza técnica e à ausência do sujeito, diante da experiência estética. O final da década de 60 foi marcado por experimentalismos, envolvendo novas expressões artísticas, tendo o corpo como objeto de interação e o espectador, como um elemento imprescindível à conclusão da obra, no que concerne especificamente aos seus efeitos de sentido.

Naquela época, o Brasil vivia um contexto sociopolítico de intensa repressão. A ditadura militar impulsionou uma "modernização conservadora no país" (FREITAS, 2004, p. 61) e, ao passo que expandiu a urbanização e a oferta de serviços, corroborou para a padronização de hábitos e fomentou a intolerância a qualquer ideologia destoante do modelo consuetudinário vigente. Diante de tal contexto, via-se uma geração de artistas e intelectuais temerosos em relação à sua produção cultural e aos problemas políticos do país e, como a adesão de artistas plásticos nas organizações de esquerda fora mínima (RIDENTI, 1993, p. 73 apud FREITAS, 2004), a atuação política destes restringia-se a manifestações isoladas.

A revolução iconográfica proposta pelo neoconcretismo fez emergir, no Brasil, artistas como Lygia Clark, Lygia Pape e Hélio Oiticica, também preocupados com a superação do objeto, com a fusão entre artista e espectador, com o rompimento da linearidade do discurso e da concepção de arte pura (SIELSKI, 2009). Em seu processo criativo, Celeida Tostes buscava incluir o espectador em sua obra pela via da prática individual e coletiva, tendo como matériaprima prioritária o barro, a partir do qual sua produção diferenciou-se sobremaneira dos artistas citados.

Segundo Santos e Neves (2010) enquanto Clark, Pape e Oiticica buscavam uma cooperação direta do espectador, Celeida detinha-se à experiência sensorial dada a partir de sua própria participação. Seu enfoque estava na integração do corpo com sua matéria-prima, de tal forma que "Passagem" foi a única performance por ela realizada, como apontam Costa e Silva (2014). Sua produção se diferenciou dos demais autores não apenas pelo uso do barro, mas também pela exploração dos sons no interior das peças produzidas, propondo assim, uma relação sensorial com o público que não dependia exclusivamente da atividade performática.

\footnotetext{
${ }^{5}$ Designamos aqui como racional, toda arte vinculada às características do concretismo, tais como objetividade, serialidade, retorno às formas puras da geometria, produção industrial em larga escala, funcionalidade, ausência de mitologia ou religiosidade, limitação da experiência artística e negação da arte artesanal e da produção de obras únicas (SANTOS; NEVES, 2010).
}

\section{POLÊM!CA $\mid$ LABORE}

Polêmica - Revista Eletrônica da Uerj - Rua São Francisco Xavier, 524, $1^{\circ}$ andar bloco D, sl.1001 • Tels.: +55 21 2334-4088 / 4087 • http://www.e-publicacoes.uerj.br/index.php/polemica/index http://www.labore.uerj.br • laboreuerj@yahoo.com.br 
Segundo Aquila, Emmanuel e Ventura (2014), Celeida era uma artista com traços modernistas, especialmente sob a ótica da ética, pois tinha um notável respeito pelos materiais, ou seja, se atentava à questão da autenticidade, no intuito de que seu trabalho refletisse a matéria, preocupações estas presentes no modernismo. Celeida era muito diferente de muitos de seus contemporâneos, visto que, inserida em um contexto artístico e político racionalista, subvertia a ordem, através de sua criatividade e de sua concepção de mundo "[...] como matériaprima em permanente mutação" (AQUILA; EMMANUEL; VENTURA, 2014, p.11). Logo, ao ampliar a concepção da conhecida década da pintura, a qual era, sobretudo, criada para durar, Celeida efetivou a arte enquanto ética, como será demonstrado adiante.

Lacan (1959-1960/2008) já asseverara que a ética está situada para além das obrigatoriedades, das leis que regulam a sociedade e, portanto, não pode ser limitada à moral. Distintamente desta, a ética da Psicanálise corrobora a abundância do desejo como ausência da direção da ação humana, dado que os ideais forjados pela cultura não são suficientes para orientar o sujeito em sua busca pela felicidade. Isto se dá, visto que o desejo enquanto pura negatividade não encontra satisfação com os objetos empíricos que lhe estão disponíveis (SAFATLE, 2017/2018).

Não obstante sempre fracassada procura por um contentamento total, Safatle (2017/2018) pondera que é somente através da afirmação do desejo que cada um pode encontrar sua mínima singularidade ${ }^{6}$, a qual não implica diretamente em formas únicas de ser. Não se trata de uma individualidade, posto que o desejo do homem é, fundamentalmente, o desejo do Outro. O que está em questão é o encontro com o desejo diante do estranhamento do Eu em relação ao sujeito.

Por este ângulo, notamos o distanciamento de Celeida em relação ao seu processo constitutivo de alienação, a socialização. Leia-se, precisamente, distanciamento, dado que separar-se da instância fundadora de identificação é uma impossibilidade. Em meio a um cenário de arte concreta, padronizada, mecanizada e industrial, atrelado a um contexto de repressão e censura, a artista, que não se reconhecia em seu papel social enrijecido de docente como aquela que dita normas e condutas, criou satisfações parciais até mesmo em seu processo de ensino, descentrando-se da matriz sociossimbólica que regia sua atuação.

\footnotetext{
${ }^{6}$ Ser singular, aqui, não significa ser radicalmente diferente, oposto ao universal, ou ainda, desvencilhado do Outro. Muito pelo contrário, é utilizar-se dos códigos comuns, como a linguagem e suas normas, para criar algo frente ao qual o sujeito se reconheça (NUNES, 2017).
}

\section{POLÊM!CA $\mid$ LABORE}

Polêmica - Revista Eletrônica da Uerj - Rua São Francisco Xavier, 524, $1^{\circ}$ andar bloco D, sl.1001 • Tels.: +55 21 2334-4088 / 4087 • http://www.e-publicacoes.uerj.br/index.php/polemica/index http://www.labore.uerj.br • laboreuerj@yahoo.com.br 
Aquila, Emmanuel e Ventura (2014) contam que Celeida trabalhava com uma metodologia de ensino livre, através da qual os estudantes deviam criar uma linguagem que lhes fosse singular, razão pela qual não ministrava técnicas ou fórmulas determinadas. A prioridade estava no fazer sem compromisso, nas descobertas, criações e combinações possíveis. Se havia uma regra, essa era, justamente, o desvio da atividade original do material, preservando assim também, sua ética para com a matéria.

Celeida ilustra a premissa de Bataille (1957/2017) - de que a razão só é superada pela violência, ou seja, pela ascensão do desejo erótico - para além de sua práxis docente. Sua violência reside no não ceder de seu desejo, ou seja, em seu reconhecimento enquanto indeterminação (SAFATLE, 2017/2018). Isto se dá, visto que sua escolha pela escultura em barro em oposição à gravura demonstra sua recusa ao fazer artístico da época, pautado primordialmente na arte concreta geometrizada e erudita, diante do qual ela não se reconhecia.

A partir da inadequação entre os objetos empíricos e seu desejo, diante da qual tudo deixa a desejar, Celeida pôde desejar ainda mais e, portanto, ser criadora de sua experiência artística. Assim, o fez pela fusão entre a arte popular e a arte erudita, pois ao abarcar tecelagem e cerâmica, desafiou o estigma de que tais manifestações artísticas eram meros artesanatos e, por isso, tinham menos qualidade.

Além disso, o uso do barro como matéria-prima deu o toque de atemporalidade ao seu trabalho, incluindo características que vão do neolítico à atualidade (AQUILA; EMMANUEL; VENTURA, 2014). Celeida, ao usar o barro, massa perecível, desistiu da ilusão de continuidade de sua obra, atendo-se à experiência que esta pode oferecer enquanto objeto de interpretação livre, mutante e aberta a todo o possível.

Bataille (1957/2017, p. 41) pondera que "a passagem do estado normal ao desejo erótico supõe em nós a dissolução relativa do ser constituído na ordem descontínua", ou seja, para assumir tal desejo, faz-se necessário romper com a ilusão da duração, das concepções vigentes e reguladoras que embalam o ser em seu sono tranquilo. Celeida estava desperta e compreendia muito bem sua atuação: "Minha tarefa como artista plástica não se atém somente à consciência da questão estética, mas procura dirigir-se ao elemento questionador do cotidiano, ao essencial na relação com o mundo" (COSTA, 2014, p. 101). Assim era ela, uma mulher que abandonara a nostalgia da continuidade perdida e entregara-se ao perecível.

\section{POLÊM!CA $\mid$ LABORE}

Polêmica - Revista Eletrônica da Uerj - Rua São Francisco Xavier, 524, $1^{\circ}$ andar bloco D, sl.1001 • Tels.: +55 21 2334-4088 / 4087 • http://www.e-publicacoes.uerj.br/index.php/polemica/index http://www.labore.uerj.br • laboreuerj@yahoo.com.br 
A suspensão das certezas e o desapego de Celeida em relação à definição de 'obra pronta' e 'obra produto' era tal que utilizava a urina como método de oxidação, ateava fogo em buracos profundos para serem vistos por pilotos de aviões e manipulava até mesmo o lixo da lixeira, criando a partir de sua fermentação, uma massa plástica. Plástica como Celeida, que desconcertava os partidários do concretismo ao transformar utensílios do cotidiano em arte. Um pilão não servia simplesmente para pilar. Da casa do João de Barro (Figura 1) muitas nuances podiam ser criadas. Era assim que tais objetos passavam a ser encarados como forma, a partir da qual se tornavam desutilitários, como destaca Costa e Silva (2014).

Figura - 1: Aldeia Funariusrufus. Instalação, I Bienal do Barro da America Museo de Arte Contemporânea Sofia Imber, Caracas, Venezuela

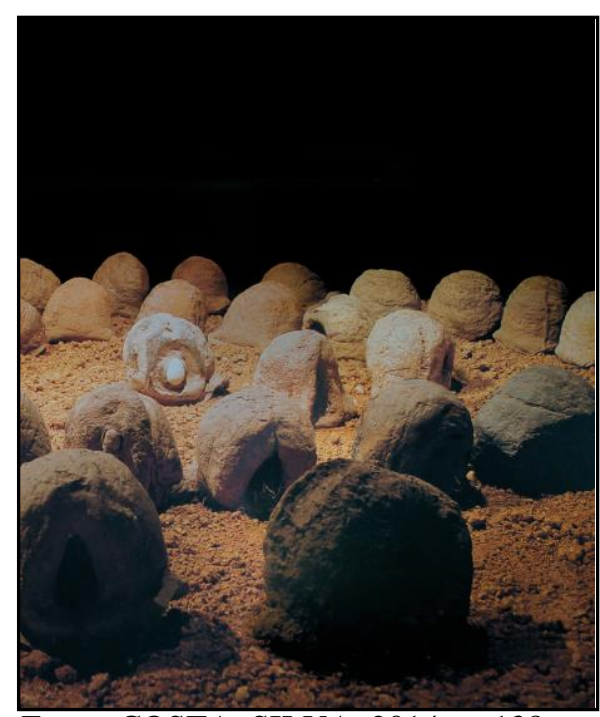

Fonte: COSTA; SILVA, 2014, p. 138.

Logo, Celeida recorria, como indicara Bataille (1949/2016, p. 19), a princípios situados “[...] para além do útil e do prazer". A premissa do autor é que o sentido da própria palavra útil já olvida a questão fundamental e que o sentido último da atividade encontra-se na perda, ou ainda, na restituição ao mundo sagrado daquilo que o consumo servil tornou profano. Neste mesmo sentido, notamos que a artista entregava-se ao dispêndio improdutivo, à inutilidade, reduzia o barro à coisa, negava as relações utilitárias do mundo profano e assim, colocava ovos na porta da casa do João de Barro, misturava barro com saliva e criava a sua própria tecnologia.

Não obstante, é com "Passagem" (Figura 2) que Celeida reformula radicalmente sua experiência artística (NAME, 2014). Essa obra é a síntese de suas características fundamentais, pois funde escultura e performance e enfatiza o processo de criação da obra sem preocupação

\section{POLÊM!CA $\mid$ LABORE}

Polêmica - Revista Eletrônica da Uerj - Rua São Francisco Xavier, 524, $1^{\circ}$ andar bloco D, sl.1001 • Tels.: +55 21 2334-4088 / 4087 • http://www.e-publicacoes.uerj.br/index.php/polemica/index http://www.labore.uerj.br • laboreuerj@yahoo.com.br 
com a duração, visto que até mesmo a destruição do material compõe sua obra. Além disso, tem a experiência como o ponto crucial de aproximação entre arte e vida e articula uma criação perpassada pela coletividade, pois sua efetivação só foi possível com a ajuda de outras duas mulheres e de um fotógrafo.

Figura - 2: Passagem, 1979

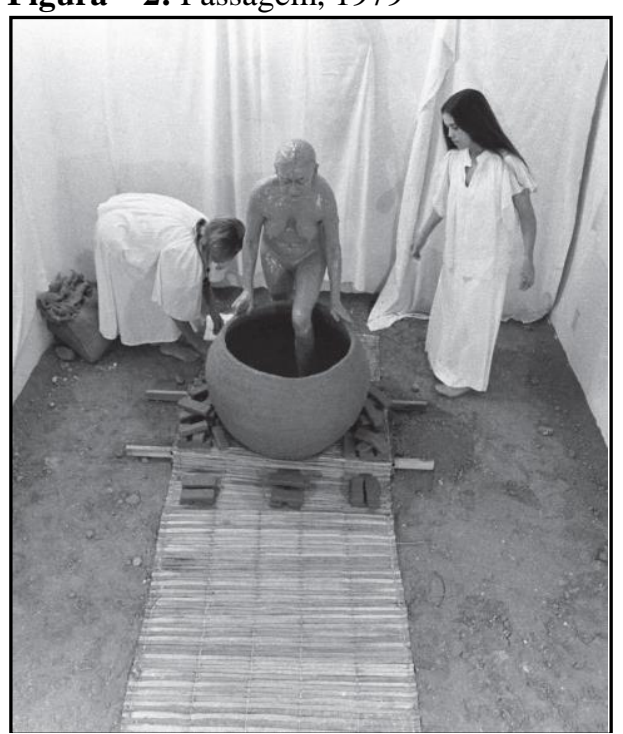

Fonte: COSTA; SILVA, 2014, p. 33.

Em uma proporção profundamente diferente de suas obras anteriores, 'Passagem' foi realizada dentro de seu próprio apartamento, ocasião em que todo seu corpo foi coberto com argila líquida, entrou em um pote de barro cru, que foi posteriormente lacrado por suas assistentes e lá permaneceu por algum tempo. Por fim, projetou seu corpo para frente, a peça tombou e Celeida foi lançada para fora. A experiência foi fotografada por Henri Stahl e integrara uma exposição individual da artista na Funarte (NAME, 2014).

No tocante ao registro de sua performance, urge destacar o que Barthes (1980/1984) afirma sobre a fotografia

[...] não sei o que a sociedade faz de minha foto, o que ela lê nela (de qualquer modo, há tantas leituras de uma mesma face); mas quando me descubro no produto dessa operação, o que vejo é que me tornei Todo-Imagem, isto é, a Morte em pessoa; os outros - o Outro - desapropriam-me de mim mesmo, fazem de mim, com ferocidade, um objeto, mantêm-me à mercê, à disposição, arrumado em um fichário, preparado para todas as trucanagens sutis [...]. (BARTHES, 1980/1984, p. 28-29).

Neste sentido, vemos que a fotografia reproduz o que nunca mais irá se repetir, dado que não existe uma continuidade na cena fotografada, pois o enquadramento fotográfico mata

\section{POLÊM!CA $\mid$ LABORE}

Polêmica - Revista Eletrônica da Uerj - Rua São Francisco Xavier, 524, $1^{\circ}$ andar bloco D, sl.1001 • Tels.: +55 21 2334-4088 / 4087 • http://www.e-publicacoes.uerj.br/index.php/polemica/index http://www.labore.uerj.br • laboreuerj@yahoo.com.br 
tudo o que acontece ao objeto. Assim, aberta à contingência, ao real, ela não é nada mais do que o que vemos, de modo que as reflexões possíveis acerca da obra dar-se-ão tão somente com o resgate de informações do passado. Eis porque recorremos aos registros escritos e às entrevistas de Celeida sobre sua experiência, para fazermos nossas inferências relativas à sua obra.

Em uma entrevista cedida pelo artista plástico Jorge Emmanuel, em meados dos anos 1990, Celeida falara sobre a importância de tal trabalho

\begin{abstract}
Passagem foi, para mim, a oportunidade onde mais pertenci à minha matéria prima de trabalho - ao barro, à terra. A terra como grande ventre, como um cosmos. Preenchi o vazio do pote com meu corpo coberto de barro. Com os sons que saíam de mim, mas não correspondiam a palavras, encontrei o silêncio. Foi uma viagem ao barro, o contato com alguma coisa muito subterrânea. $\mathrm{O}$ meu próprio processo de vida, o processo de vida muito para trás e o processo de vida mais próximo. Quando eu digo para trás, estou dizendo para trás mesmo, no espaço; alguma coisa que não sei definir, que não sei explicar e não conheço. Mas eu tive contato com alguma coisa que era como um útero. Eu não posso ficar falando isso assim, desse jeito, porque é uma experiência muito íntima. Eu acho que trepei com o barro, sabe? Foi como se eu tivesse dado uma trepada com alguma coisa que não saberia definir. Foi muito, muito importante esse trabalho (FERREIRA; SILVA, 2014, p. 225, grifo nosso).
\end{abstract}

Diante de sua experiência, Celeida reconhece sua posição de não-saber, ou ainda, em termos lacanianos, de "não-toda a se situar na função fálica” (LACAN, 1972-1973/2008, p.79), pois ainda que intentasse preencher o vazio do pote e buscasse uma verdade última sobre si, acabou deparando-se com o silêncio, o indefinível, o inexplicável e o desconhecido, próprios do gozo feminino. Esse encontro despojou-a de toda onipotência, fazendo-a pertencer ao barro, sua matéria-prima e a contrapor-se ao referencial fálico que pretende a completude e a autossuficiência. Assim, a partir da indefinição, Celeida abriu-se para a possibilidade de pensar a alteridade e entregou-se à infinidade e à multiplicidade da experiência interior, ou ainda, da feminilidade.

Não é sem motivos que 'Passagem' é situada pelos críticos como o momento em que a artista " $[. .$.$] nasceu para novas possibilidades artísticas e se despediu de outras, enfatizando$ potências antes pouco exploradas e silenciando outras já mais reconhecíveis e menos interessantes para sua pesquisa" (NAME, 2014, p. 53). Apesar de a artista não ter realizado outros trabalhos performáticos, tal pontuação se deve ao fato de que 'Passagem' inaugurou uma nova forma de atuação artística para Celeida, como a possibilidade de superação do objeto em detrimento da valorização da experiência barro-corpo-alteridade. Estas características podem

\title{
POLÊM!CA $\mid$ LABORE
}

Polêmica - Revista Eletrônica da Uerj - Rua São Francisco Xavier, 524, $1^{\circ}$ andar bloco D, sl.1001 • Tels.: +55 21 2334-4088 / 4087 • http://www.e-publicacoes.uerj.br/index.php/polemica/index http://www.labore.uerj.br • laboreuerj@yahoo.com.br 
ser observadas também em seus projetos comunitários posteriores como a instalação no "Morro do Chapéu Mangueira"7, "Amassadinhos"8 e "O muro"9.

Assim, o processo passou a ser encarado por Celeida como um elemento de extrema importância e que deveria ser experimentado em suas últimas consequências. Esta concepção repercutiu também em sua práxis docente, a partir da qual a professora passou a rejeitar toda e qualquer manifestação puramente estética. $\mathrm{O}$ aluno poderia produzir uma escultura de grande beleza, mas se não tivesse refletido e experimentado de algum modo sua criação, ela imediatamente destruía o trabalho e pedia que o estudante recomeçasse (COSTA; SILVA, 2014).

Ainda sobre sua experiência, Celeida destacara

\begin{abstract}
A partir da gravura emmetal, deu-se [...] a passagem para a esmaltação em metal. A retomada de Memórias da Infância na roça, na fazendade Campo Alegre, no Estado do Rio, pouco a pouco foi se apropriando das matérias primas da esmaltação, e que fazem parte do universo da cerâmica. Essa passagem foi vagarosa, até que no evento 'Passagem' assumiu todo o vigor de que precisava. (TOSTES, 1989, p. 5 apud SANTOS, 2011, p. 120).
\end{abstract}

A ponderação de Celeida comprova como 'Passagem' realmente foi um marco para sua produção. Pode-se destacar que o barro comporta uma metáfora de extrema relevância para seu trabalho, visto que ele, enquanto matéria plástica e cíclica, saiu de sua forma e função original, para tornar-se um grande pote e posteriormente ser destruído, retornando à sua forma, pronto para ser novamente moldado e (re)construído. Assim foi também Celeida, que entrou ainda vinculada com uma arte regida por normas e padrões herdados de sua formação em gravura e, finalmente, saiu, não despojada de sua origem, mas aberta a todo o possível.

\footnotetext{
${ }^{7}$ Trabalho de cerâmica com barro fundado por Celeida, a partir de 1980, na comunidade Morro do Chapéu Mangueira, originário do projeto Formação de Centros de Cerâmica Utilitária nas Comunidades de Periferia Urbana do Rio de Janeiro - Chamadas Favelas. A proposta da artista era fomentar a recuperação de memórias dos moradores do morro, a maioria deles migrantes de áreas rurais, para assim, transformar em arte e fonte de renda, os saberes populares, cada qual a seu modo (NAME, 2014).

${ }^{8}$ Esta obra compôs a $21^{a}$ Bienal Internacional de São Paulo e constituiu-se na exposição de três painéis em uma parede de $36 \mathrm{~m}^{2}$ com 20 mil Amassadinhos de barro, os quais foram produzidos com 4,5 toneladas de barro e terra de vários lugares do Rio de Janeiro. Este projeto contou com a colaboração dos detentos do Presídio Frei Caneca, dos moradores do Morro do Chapéu Mangueira, dos alunos e professores do Parque Lage, dos visitantes, artistas e crianças do MAM-RJ, das prostitutas da Vila Rosali, de empregadas domésticas, de meninos em situação de rua e dos alunos e professores da Coppe/UFRJ (FERREIRA; SILVA, 2014).

${ }^{9}$ Este trabalho, que ficou apenas na idealização de Celeida, pois não foi aceito na Bienal e consistia na proposta da construção de um muro de adobe pelos detentos do presídio Frei Caneca. A ideia era que eles produzissem um muro com recados dentro da prisão e posteriormente, o libertassem, fazendo com que ele se tornasse um "desmuro" (AQUILA; EMMANUEL; VENTURA, 2014).
}

\title{
POLÊM!CA $\mid$ LABORE
}

Polêmica - Revista Eletrônica da Uerj - Rua São Francisco Xavier, 524, $1^{\circ}$ andar bloco D, sl.1001 • Tels.: +55 21 2334-4088 / 4087 • http://www.e-publicacoes.uerj.br/index.php/polemica/index http://www.labore.uerj.br • laboreuerj@yahoo.com.br 
Cumpre asseverar que as transgressões empreendidas por Celeida tanto em 'Passagem', quanto em suas demais obras, não compreendem um retorno à natureza ou à animalidade, muito pelo contrário, ela “[...] suspende o interdito sem suprimi-lo" (BATAILLE, 1957/2017, p. 59). A artista rompeu, portanto, com a continuidade das normas concretistas, diante das quais não se identificava e criou novas propostas, como sua preocupação para com a busca pelo movimento incessante, a preservação da ética do material, a transformação da obra e as experiências possíveis tanto para o artista, quanto para o expectador-artista. Assim, imprescindíveis foram os interditos para que a partir deles, Celeida pudesse criar uma narrativa que lhe fosse singular.

Apesar de sua criação inovadora, é necessário considerar a afirmação de Butler de que

[...] não existe nenhum 'eu' que possa se separar totalmente das condições sociais de seu surgimento, nenhum 'eu' que não esteja implicado em um conjunto de normas morais condicionadoras, que, por serem normas, têm um caráter social que excede um significado puramente pessoal ou idiossincrático (BUTLER, 2005/2017, p. 18).

A ponderação da autora remete à infância de Celeida, à sua vida na fazenda e suas brincadeiras com o barro, bem como ao seu envolvimento artístico, durante a ditadura militar, situações estas que expressam condições sociossimbólicas, diante das quais a artista não escolheu participar. Não obstante, foi justamente inserida neste contexto de restrições, que ela pode colocar o seu ser em questão, precisamente, por não se reconhecer nos termos que lhe estavam acessíveis.

Com isto, vemos que o desejo está na base da lei, a qual se apresenta, sobretudo, paradoxal, pois ao passo que interdita, aponta também para o desejo (LACAN, 19591960/2008), via pela qual cada sujeito pode encontrar sua singularidade. Entretanto, dado que é impossível qualquer reconhecimento sem o Outro, o desejo enquanto inconquistável não pode ser transposto, mas isto não significa que o sujeito deva renunciar a ele. Safatle (2017/2018) afirma que é justamente no estranhamento entre o 'Eu' e o 'si mesmo' que o desejo desponta, deixando sempre a marca de sua ausência, a partir da qual pode ele desejar mais, ainda.

Vê-se, portanto, que a vida e a obra de Celeida são perpassadas por um desejo que se inseriu no furo do Outro e que, dada a impossibilidade de se desvencilhar totalmente desta instância que também a faz desejar, ela pôde criar alternativas para se articular entre interdito e transgressão, experimentando assim, um encontro com a feminilidade. Celeida era como barro,

\section{POLÊM!CA $\mid$ LABORE}

Polêmica - Revista Eletrônica da Uerj - Rua São Francisco Xavier, 524, $1^{\circ}$ andar bloco D, sl.1001 • Tels.: +55 21 2334-4088 / 4087 • http://www.e-publicacoes.uerj.br/index.php/polemica/index http://www.labore.uerj.br • laboreuerj@yahoo.com.br 
uniu-se aos vazios, penetrou os vãos formando uma intensa orgia, suspendeu suas verdades e por fim, criou novas moradas para si, reinventando suas relações com o mundo.

\section{Conclusão}

A arte de Celeida carrega as marcas do Outro, registros estes que não tornam seu trabalho menos singular. É inegável o encontro de sua história pessoal, seu encontro com a índia Navajo Maria Martinez e toda sua experiência de estudo e produção artística com sua escolha do barro como matéria-prima. Também, sua trajetória é perpassada pelo contexto de opressão e censura da ditadura militar e pelas transformações no mundo da arte, mais precisamente pelo surgimento do movimento neoconcretista.

Não obstante, é justamente a partir deste encontro fracassado com o Outro que Celeida pode ser criadora de sua própria história. Safatle (2017/2018, p. 23) destaca que toda socialização é alienação, pois implica em "[...] ter seu modo de pensar e desejar moldado por um outro", o que enfatiza a indissociabilidade do sujeito com o Outro, sua instância de identificação. Assim, não havendo uma existência que seja pura positividade, ou melhor, na impossibilidade de uma adequação entre as representações e os objetos da experiência, é que o desejo da artista pode advir em sua negatividade.

Como constatamos, Celeida criou sua própria tecnologia, fundiu arte popular e erudita, rompeu com a concepção de continuidade da obra, suspendeu as noções de arte pronta e arte produto, desenvolveu sua metodologia de ensino e ainda rejeitou a normatividade e linearidade proposta pelo concretismo. As transgressões empreendidas por ela levam à conclusão de que estas só foram possíveis em razão dos interditos que intentavam regulamentar seu fazer artístico.

Celeida não reforçou seu processo constitutivo de alienação e entregou-se, nos termos de Bataille (1957/2017), à dissolução das formas socialmente constituídas que buscam uma continuidade imperecível. O encontro da artista com o erotismo, ou ainda, com a feminilidade, deu-se justamente no momento em que ela se viu não representada por suas referências de origem, apesar de toda inscrição sociossimbólica que a perpassava. É justamente por conservar os interditos que Celeida pôde criar a sua experiência artística, deslocando-se entre interdito e transgressão de modo fluido e descontínuo, sem negar a alteridade que a constitui.

\section{POLÊM!CA $\mid$ LABORE}


Eis porque a artista efetivou transgressões bem-sucedidas, já que conservou o interdito, para dele gozar (BATAILLE, 1957/2017). Com isto, criou suas próprias regras e normas, preocupações estas que são o motor de toda transgressão genuína. Celeida colocou seu ser em questão ao opor-se aos juízos habituais e abriu-se à experiência interior, precisamente por desistir de querer ser tudo, de buscar por uma completude e por respostas que a pudessem definir enquanto matéria pronta e acabada.

O processo de socialização, apesar de implicar no que Butler (2005/2017, p. 147) designou como “[...] esfera em que sou desapossada de mim mesma [...]", resulta também em um deslocamento do sujeito de seu campo de autossuficiência e onipotência. Deste modo, a artista escolheu posicionar-se no gozo feminino, abandonando suas certezas e a necessidade de duração. Nos termos de Bataille (1943/1992, p. 75) “o não-saber desnuda” e assim foi Celeida: desnudou-se das concepções artísticas do concretismo, adotou o barro como matéria-prima de seu trabalho, mesmo tendo se graduado em gravura e abriu-se a todo o possível. Celeida flerta com o caos. Celeida dispensa rótulos e definições. Celeida é.

\section{Referências}

AQUILA, L.; EMMANUEL, J.; VENTURA, R. Celeida Tostes, dama e operária à espreita da mutação. In: COSTA, M. L.; SILVA, R. (Org.). Celeida Tostes. Rio de Janeiro: Aeroplano, 2014. p. 11- 27.

BARTHES, R. (1980). A câmara clara: nota sobre a fotografia. Rio de Janeiro: Nova Fronteira, 1984.

BATAille, G. (1943). A experiência interior. Ática: São Paulo, 1992.

BATAille, G. (1949). A noção de dispêndio. In: BATAILlE, G. A parte maldita, precedida de “A noção de dispêndio". 2. ed. Belo Horizonte: Autêntica, 2016. p. 19-33.

BATAILlE, G. (1928). História do olho. 1. ed. São Paulo: Companhia das Letras, 2018.

BATAILLE, G. (1957). O erotismo. 1. ed. São Paulo: Autêntica, 2017.

BUTLER, J. (2005). Relatar a si mesmo: crítica da violência ética.1. ed. Belo Horizonte: Autêntica, 2017.

BUTLER, J. (1990). Problemas de gênero: feminismo e subversão da identidade. 16. ed. Rio de Janeiro: Civilização Brasiliense, 2018.

COSTA, M. L. Celeida Tostes: a essência alquímica. In: COSTA, M. L.; SILVA, R. (Org). Celeida Tostes. Rio de Janeiro: Aeroplano, 2014. p. 101- 104.

COSTA, M. L.; SILVA, R. (Org.). Celeida Tostes. Rio de Janeiro: Aeroplano, 2014. FERREIRA, I.; SILVA, R. Biografia. In: COSTA, M. L.; SILVA, R. (Org.). Celeida Tostes. Rio de Janeiro: Aeroplano, 2014. p. 220-259.

\section{POLÊM!CA $\mid$ LABORE}

Polêmica - Revista Eletrônica da Uerj - Rua São Francisco Xavier, 524, $1^{\circ}$ andar bloco D, sl.1001 • Tels.: +55 21 2334-4088 / 4087 • http://www.e-publicacoes.uerj.br/index.php/polemica/index http://www.labore.uerj.br • laboreuerj@yahoo.com.br 
FREITAS, A. Poéticas políticas: as artes plásticas entre o golpe de 64 e o AI-5. História: Questões e Debates, Curitiba, n. 40, p. 59-90, 2004.

FREUD, S. (1933). A feminilidade. In: FREUD, S. O mal-estar na civilização, novas conferências introdutórias à psicanálise e outros textos. São Paulo: Companhia das Letras, 2010. p. 263-293.

FREUD, S. (1900). A interpretação dos sonhos. 2. ed. Rio de Janeiro: Imago, 1996.

FREUD, S. (1920-1923). A identificação. In: FREUD, S. Psicologia das massas e análise do eu e outros textos. 4. ed. São Paulo: Companhia das Letras, 2012. p. 46-53.

FREUD, S. (1925). Algumas consequências psíquicas da distinção anatômica entre os sexos. In: FREUD, S. Obras psicológicas completas de Sigmund Freud. 1. ed. Rio de Janeiro: Imago, 1996. p. 273- 286.

FREUD, S. (1914). Sobre o narcisismo: uma introdução. In: FREUD, S. Edição Standard Brasileira das Obras Psicológicas Completas. 2a ed. Rio de Janeiro: Imago, 1987. p. 83-119.

QUINET, A. Os outros em Lacan. Rio de Janeiro: Zahar, 2012.

LACAN, J. (1960-1962). A identificação. Recife: Centro de Estudos Freudianos do Recife, 2003.

LACAN, J. (1966). Diretrizes para um Congresso sobre a sexualidade feminina. In: LACAN, J. Escritos. 1. ed. Rio de Janeiro: Zahar, 1998a. p. 734-745.

LACAN, J. (1966). O estádio do espelho como formador da função do eu. In: LACAN, J.

Escritos. Rio de Janeiro: Zahar, 1998b. p. 96-103.

LACAN, J. (1971). O homem e A mulher. In: LACAN, J. O Seminário, livro 18: de um discurso que não fosse semblante. Rio de Janeiro: Zahar, 2009. p.22-36.

LACAN, J. (1959-1960). O Seminário, livro 7: a ética da psicanálise.2. ed. Rio de Janeiro: Zahar, 2008.

LACAN, J. (1971-1972). O Seminário, livro 19: ...ou pior.1. ed. Rio de Janeiro: Zahar, 2012.

LACAN, J. (1972-1973). O Seminário, livro 20: mais, ainda.1. ed. Rio de Janeiro: Zahar, 2008.

NAME, D. Da lama ao caos, do caos à lama. In: COSTA, M. L.; SILVA, R. (Org.). Celeida Tostes. Rio de Janeiro: Aeroplano, 2014. p. 53-81.

NUNES, T. R. Bataille, Lacan e a Tautologia do singular. 2012. 261f. Tese (Doutorado em Psicologia Clínica e Cultura) - Universidade de Brasília, Brasília, DF, 2012.

NUNES, T. R. Bataille, Lacan e a tautologia do singular: uma leitura do saber-fazer lacaniano a partir da relativa viabilidade de Bataille. Arte e Filosofia, Ouro Preto, n. 23, p.147-166, 2017.

RIVERA, T. (2002). Arte e Psicanálise. 2. ed. Rio de Janeiro: Jorge Zahar, 2005.

RIVERA, T. O sujeito está na arte. Cadernos de estética aplicada, Niterói, n. 15, p. 236-247, 2014.

SAFATLE, V. (2017). Introdução a Jacques Lacan. 4. ed. Belo Horizonte: Autêntica, 2018.

SANTOS, M. A. L.; NEVES, A. F. Arte concreta: racionalismo e abstração como contribuições para o design um estudo na obra de Geraldo de Barros. Educação gráfica, n. 14, p. 70-89, 2010.

SANTOS, E. R. Celeida Tostes; o barro como elemento integrativo na Arte Contemporânea. 2011. 205 f. Dissertação (Mestrado em Artes Visuais) - Instituto de Artes, Universidade Estadual Paulista, São Paulo, 2011.

\section{POLÊM!CA $\mid$ LABORE}

Polêmica - Revista Eletrônica da Uerj - Rua São Francisco Xavier, 524, $1^{\circ}$ andar bloco D, sl.1001 • Tels.: +55 21 2334-4088 / 4087 • http://www.e-publicacoes.uerj.br/index.php/polemica/index http://www.labore.uerj.br • laboreuerj@yahoo.com.br 
SIELSKI, I. M. Celeida Tostes no contexto do campo ampliado: do espaço da arte ao espaço da vida. In:ENCONTRO DA ASSOCIAÇÃO NACIONAL DE PESQUISADORES EM ARTES PLÁSTICAS TRANSVERSALIDADES NAS ARTES VISUAIS, 18., 2009, Salvador. Anais... Salvador: Anpap, 2009. p. 582- 597.

Recebido em: 09/04/2020.

Aceito em: 02/08/2021.

\section{POLÊM!CA $\mid$ LABORE}

